PRACE GEOGRAFICZNE

zeszyt 157, 2019, 33-49

doi: 10.4467/20833113PG.19.008.10624

Instytut Geografii i Gospodarki Przestrzennej UJ

Komisja Geograficzna, Polska Akademia Umiejętności

Wydawnictwo Uniwersytetu Jagiellońskiego

\title{
WYKORZYSTANIE ZNORMALIZOWANEGO RÓŻNICOWEGO WSKAŹNIKA WEGETACJI NDVI DO OCENY TEMPA ZARASTANIA ZBIORNIKÓW PRZYBRZEŻNYCH NA PRZYKŁADZIE JEZIORA GARDNO
}

Kamil Mironik, Artur Młodzik, Roman Cieśliński

\section{Using the normalized differential index of vegetation NDVI to evaluate the rate of coastal reservoirs overgrowth on the example of Lake Gardno}

\begin{abstract}
The aim of the study was to estimate the rate and extent of overgrowth of a water reservoir on the example of Lake Gardno, based on the normalized index of vegetation NDVI. In the assessment of the changes taking place in individual summer seasons within the lake basin a thorough analysis was made based on satellite imagery performed for the years 2000-2014. The main assumption was to develop an appropriate method to determine the extent of expansion of water vegetation on the example of the selected lake. Preliminary results were compiled with monthly average air temperatures and monthly mean precipitation totals, then a detailed analysis was performed to demonstrate the relationships between the effective overgrowth and local meteorological conditions. The observed changes in the ever-growing litoral zone allowed us to suppose that Lake Gardno is going to disappear.
\end{abstract}

Keywords: overgrowth, NDVI index, coastal lake, vegetation, correlation, expansion

Zarys treści: Rozwój roślinności wodnej w strefie litoralnej znacząco zmienia charakter bezpośredniego otoczenia jeziora. Jednakże, na proces zanikania ma wpływ nie tylko bujna sukcesja roślinności, ale także dostawa materiału dennego wprowadzanego poprzez cieki zasilające. 
Celem pracy jest oszacowanie tempa i wielkości zarastania zbiorników przymorskich na przykładzie jeziora Gardno, w oparciu o znormalizowany indeks wegetacji NDVI. W ocenie zachodzących zmian, postępujących w poszczególnych sezonach letnich w obrębie niecki jeziornej, posłużono się dokładną analizą na podstawie zdjęć satelitarnych wykonywanych w latach 2000-2014. Głównym założeniem było opracowanie odpowiedniej metody pozwalającej określić zasięg ekspansji roślinności wodnej w jeziorze. Wstępne wyniki zestawiono z wartościami średniej miesięcznej temperatury powietrza oraz średnich miesięcznych sum opadów atmosferycznych pochodzących ze stacji zlokalizowanej w Łebie. Następnie wykonano szczegółową analizę mającą na celu wykazanie zależności między efektywnym zarastaniem a oddziaływaniem lokalnych warunków meteorologicznych takich jak temperatura powietrza czy warunki pluwialne. Zaobserwowane zmiany stale powiększającej się strefy litoralnej pozwalają wskazać postępujący proces zanikania jeziora Gardno. Oszacowano, iż w ciągu roku roślinność porastająca brzegi jeziora Gardno ulega zwiększeniu o około 0,5 ha, jednakże przyrost charakteryzuje się raz większym, raz mniejszym stopniem podczas każdego sezonu wegetacyjnego.

Stowa kluczowe: zarastanie, indeks NDVI, jezioro przymorskie, wegetacja, korelacja, ekspansja

\section{Wstęp}

Jezioro Gardno, stanowiące przykład jeziora przybrzeżnego polskiej strefy brzegowej południowego Bałtyku, usytuowane jest w północnej Polsce, na obszarze Niziny Gardnieńsko-Łebskiej. Główną rzeką zasilającą nieckę jeziora jest jedna z największych rzek przymorskich - Łupawa, która doprowadza do jeziora około 92\% wód potamicznych (ryc. 1).

Specyfika jego położenia w obrębie strefy brzegowej południowego Bałtyku wpływa na indywidualny charakter tego jeziora na tle pozostałych zbiorników zlokalizowanych nieco bardziej w głębi lądu. Determinowane jest to poprzez wzajemne oddziaływanie dwóch środowisk - wodnego (morskiego) i lądowego.

Według podziału Polski na regiony fizycznogeograficzne Kondrackiego (2000) misa jeziora Gardno leży w zasięgu dwóch mezoreginów: w większości w granicach Wybrzeża Słowińskiego (313.41) oraz niewielka część południowo-wschodnia w obrębie Wysoczyzny Damnickiej (313.44).

Jednym z elementów wpływających na zanik powierzchni jezior w Polsce jest proces zarastania. Dotyczy to szczególnie jezior z szeroką strefą litoralną i z licznymi wypłyceniami (Choiński 2014). Takim przykładem jest jezioro Gardno. Ważną kwestią przyspieszającą taki stan rzeczy są między innymi lokalne uwarunkowania. Przykładem takich działań jest ingerencja człowieka poprzez stosowanie zabiegów melioracyjnych na danym terenie. Jezioro Gardno znajduje się na obszarze, gdzie były przeprowadzane melioracje w postaci gęstej sieci rowów i kanałów odwodnieniowych. Zanikanie jezior uzależnione jest także warunkami zlewni. Wpływ na to mają niewielkie zasoby wodne, a skutkami są: podatność na zanieczyszczenia, zbyt 


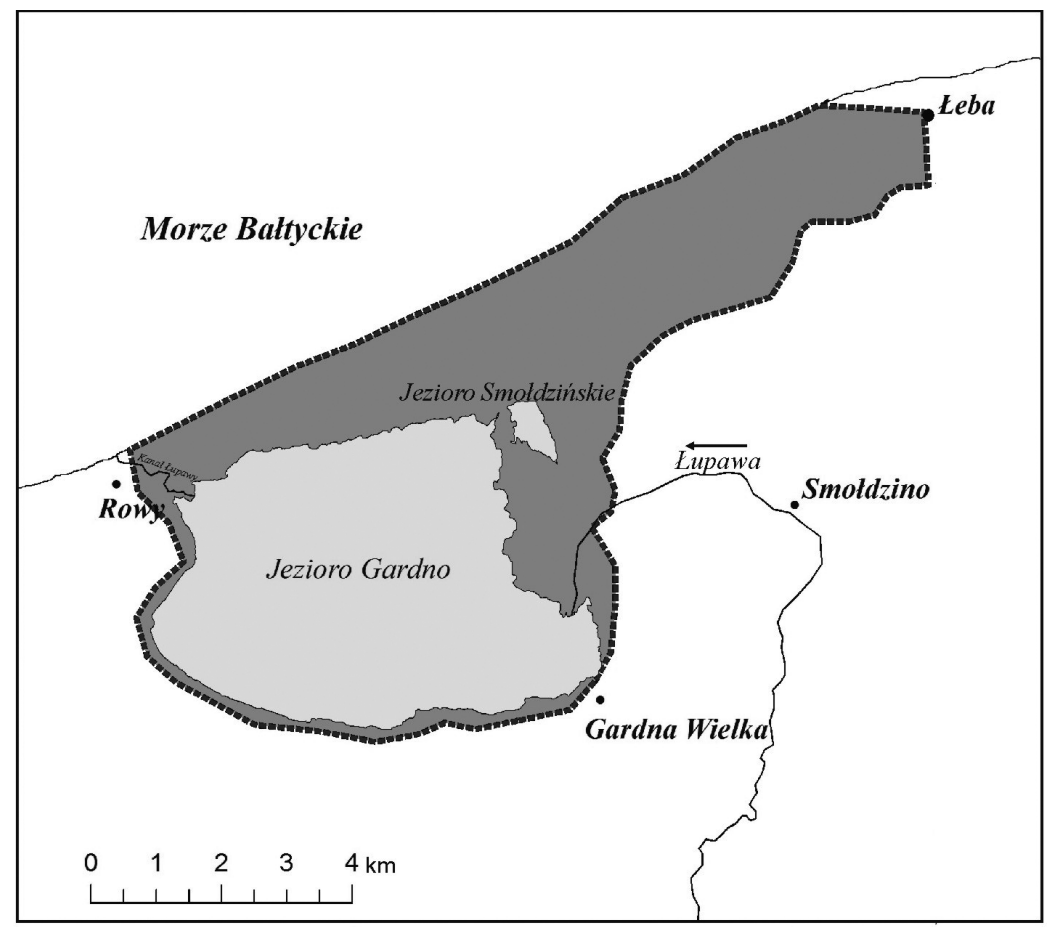

Ryc. 1. Lokalizacja obszaru badań na tle zachodniej części Niziny Gardnieńsko-Łebskiej Fig. 1. Location of the research area in the western part of the Gardno-Lebsko Lowland

niska wymiana wód oraz duża dostawa osadów dennych, powodująca użyźnienie wód w substancje biogeniczne w efekcie zjawiska resuspensji i miksji wód (Choiński, Ptak 2008; Choiński 2014).

Odsłonięte zatoki oraz brzegi po nawietrznej stronie zbiornika są strefami, gdzie najlepiej rozwija się roślinność wodna. Łatwo jest rozpoznać charakterystyczne skupienia roślinności porastającej brzegi jezior, ponieważ najczęściej przybierają formę półkolistych struktur. Podatność na zanikanie wiąże się z postępującym procesem eutrofizacji oraz ze zmianą właściwości fizycznochemicznych wód. Degradacja zbiorników wodnych spowodowana jest przede wszystkim wysoce zaawansowanym poziomem rolnictwa w zlewniach bezpośrednich na skutek nawożenia pól uprawnych (Choiński, Ptak 2008; 2013).

Jezioro Gardno cechuje się jedną z większych powierzchni na tle pozostałej grupy jezior przymorskich Polski, której wielkość wynosi 2 337,5 ha. Głębokość maksymalna wynosząca 2,6 m wskazuje, iż jest to bardzo płytki zbiornik. Powierzchnia 
zlewni całkowitej wynosi $964,4 \mathrm{~km}^{2}$, a średni dopływ roczny ze zlewni $8,40 \mathrm{~m}^{3} \cdot \mathrm{s}^{-1}$. Ilość zmagazynowanej wody w niecce jeziornej szacuje się na około 30950 tys. $\mathrm{m}^{3}$, zaś wskaźnik wymiany wody osiąga wartość 8,6 (Jańczak 1997; Cieśliński 2011).

Celem głównym pracy jest przedstawienie tempa i wielkości zarastania jeziora przymorskiego w oparciu o najnowocześniejsze techniki pomiarowe w postaci zdjęć satelitarnych.

\section{Materiały i metody}

Główne prace polegały na kwerendzie materiałów źródłowych potrzebnych do opracowania tempa i kierunków zarastania jeziora. W pracy wykorzystano również znormalizowany różnicowy wskaźnik wegetacji NDVI (ang. Normalized Difference Vegetation Index). Wskaźnik ten został po raz pierwszy użyty przez Rouse'a w badaniach przeprowadzanych w 1973 r. w Stanach Zjednoczonych. Jest on wykorzystywany do badania i wykrywania obszarów wegetacji roślin, jak również jej stanu kondycyjnego (www.fotoraporty.pl). NDVI należy obliczać ze wzoru:

gdzie:

$$
\frac{N I R-R E D}{N I R+R E D}=\text { NDVI } \quad(\text { Rouse 1978) }
$$

NIR - Wartość pikseli kanału bliskiej podczerwieni

RED - Wartość pikseli kanału czerwonego

NDVI - Znormalizowany różnicowy wskaźnik wegetacji

W pracy wykorzystano dane pochodzące z jednego satelity o jednakowych parametrach (Landsat 7). Kalibracja i korekcja mogłaby zostać przeprowadzona przy użyciu SAV (Submerged Aquatic Vegetation). Oczywiście możliwa byłaby kalibracja urządzeń poprzez wykorzystanie danych pochodzących z różnych satelitów, np. z satelity Sentinel 2. Jednakże autorzy skupili się jedynie na roślinności szuwarowej i pływającej, stąd zastosowanie oryginalnego wskaźnika NDVI, który uznano za wystarczający. Jest to metoda wykorzystywana w literaturze, czego przykładem może być badanie ekosystemów wodnych z pominięciem kalibracji (Kunz, Nienartowicz 2007). Wskaźnik NDVI przyjmuje wartości od -1 do 1, przy czym wyższe wartości (jaśniejsze obszary) wyróżniają roślinność cechującą się lepszą kondycją (Rouse 1978). Spowodowane jest to różnicą w odbiciu promieniowania ze światła podczerwonego i czerwonego przez rośliny we wczesnym, jak i końcowym etapie rozwoju. Odbicie światła podczerwonego oraz czerwonego przez rośliny we wczesnym etapie rozwoju w obrębie powierzchni jeziora dalej będzie nazywane zarastaniem efektywnym.

Wskaźnik wegetacji NDVI dla jeziora Gardno zmienia się w czasie. Poczyniono szereg prób sklasyfikowania wzrastających wartości z uwagi na pokrycie oraz użytkowanie terenu. Według pracy odnoszącej się do zmienności między potencjalną 
i rzeczywistą wartością indeksu (Hargrove, Stoms 2000) wykazuje ona cechy typów: mieszanego, rolnego oraz rodzimego (Mixed, Agriculture, Native). Biorąc pod uwagę zmienność wartości wskaźnika w czasie (Kozłowska i in. 2004), w zależności od odległości od brzegu, wykazuje on cechy gruntów ornych drobnopowierzchniowych i bagien zarastających. Należy mieć jednak na uwadze, iż te wskaźniki są przystosowane do obszarów lądowych i ich zastosowanie w przypadku obszarów zarastających może być obarczone błędem z uwagi na obszar otaczający daną roślinność.

W przypadku użytej metody niezbędne stało się wykonanie przy pomocy model buildera, zaimplementowanego w oprogramowaniu ArcGis 10.2, modelu wykonującego analizę NDVI dla wybranego jeziora w określonym czasie. Do analizy wymagane jest posiadanie zdjęć satelitarnych z okresów letnich poszczególnych lat (dane satelitarne do opracowania zaczerpnięte z www.earthexplorer.usgs.gov) oraz warstwy wektorowej badanego jeziora. Analizę można również wykonać z pominięciem modelu wykorzystującego narzędzia przedstawione na rycinie 2.

Analiza wykonana jest równolegle dla dwóch wybranych okresów w celu umożliwienia użytkownikowi ustalenia dowolnego kroku czasowego badań. Narzędzie to wykorzystuje dane z kanałów spektralnych czerwonego oraz bliskiej podczerwieni do stworzenia rastrowej mapy indeksu wegetacji NDVI na obszarze badanego jeziora. Efektem jest raster z wyznaczonymi strefami efektywnego zarastania, utożsamiany ze strefą aktywnej wegetacji roślinności brzegowej. Roślinność, która mimo faktycznego istnienia nie weszła w skład analizy, nie posiada znamion efektywnej wegetacji. Innym powodem jest fakt, iż pokrywa zbyt małą powierzchnię, aby istotnie zmienić wartość indeksu NDVI dla piksela o rozdzielczości $19 \mathrm{~m}$ x 19m, na który pozwala owa analiza. Narzędzie wykorzystuje elementy zamiany rastra na warstwę punktową. Doświadczony użytkownik ma możliwość eksploracji danych i ustawia wielkość indeksu NDVI, od którego liczone jest zarastanie. Ze względu na klimat, możliwy zły stan roślinności wodnej oraz wpływ otaczającej wody dla poniższej analizy przyjęto wartość nieznacznie poniżej formalnego zera (-0.07). Należy pamiętać, iż analiza ta z uwagi na rozdzielczość rastra wynikowego najlepsze rezultaty osiąga w miejscach intensywnego zarastania, co utożsamiane jest z buforem $100 \mathrm{~m}$ od brzegu jeziora w przypadku jeziora Gardno. Z kolei badając roślinność zanurzoną, należy mieć również na uwadze głębokość penetracji promieniowania czerwonego oraz podczerwonego w głąb wody. Taka metoda ma zastosowanie jedynie na głębokościach do $2 \mathrm{~m}$ pod lustrem wody. Wyjątek może stanowić roślinność pływająca. Niniejsza praca koncentruje się tylko i wyłącznie na roślinności brzegowej i pływającej (wynurzonej ponad powierzchnię wodną). Do przeprowadzenia obliczeń wykorzystano dane z http://fotoraporty.pl/oferta/teledetekcja/ndvi/ (dostęp: 17.09.2018), https:/en.tutiempo.net/climate/poland.html (dostęp: 12.12.2017), https:/earthexplorer.usgs.gov/ (baza danych) (dostęp: 17.09.2018). 


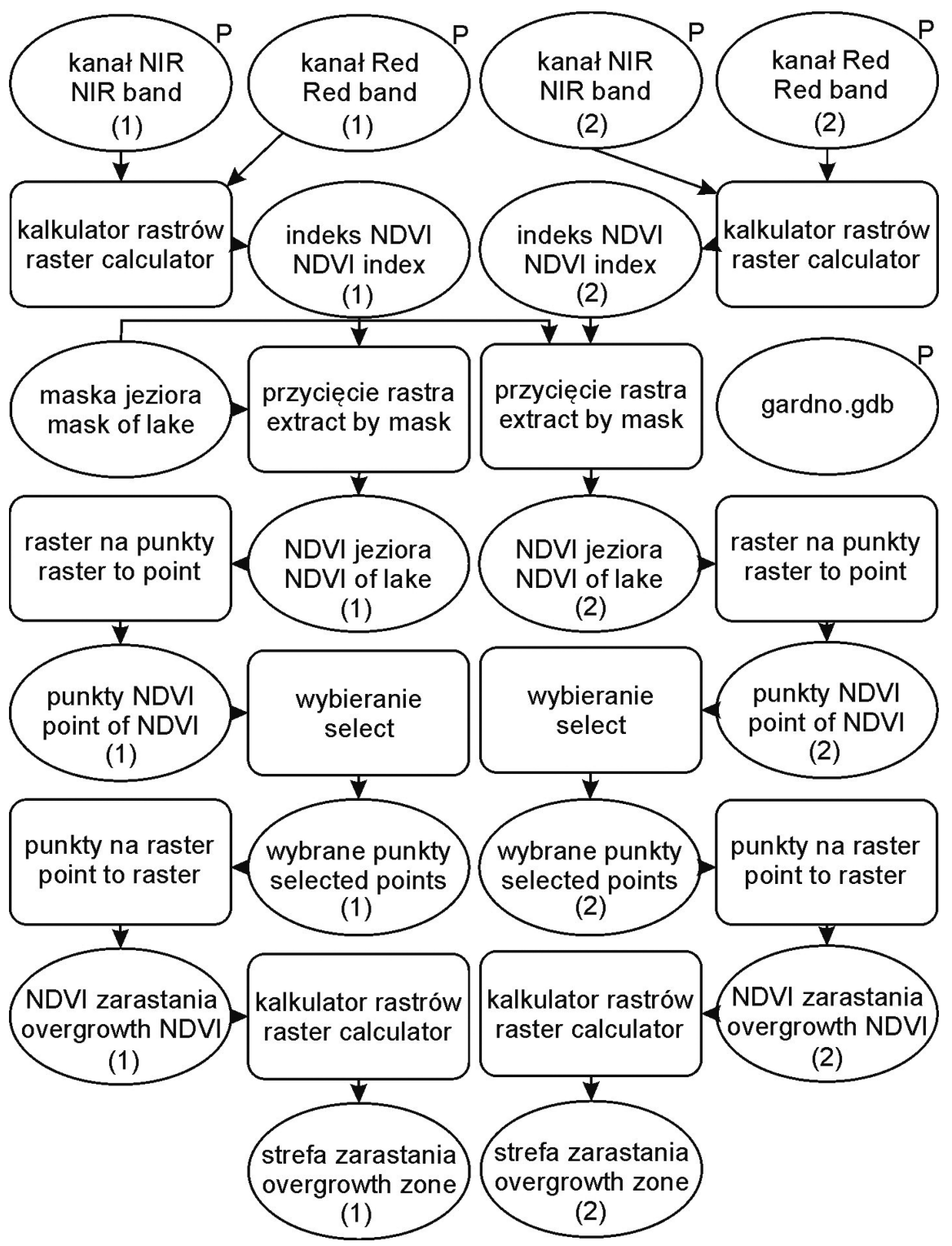

Ryc. 2. Model przeprowadzonej analizy wykorzystany przy wyznaczeniu stref efektywnego zarastania

Fig. 2. Analysis model used to design effective overgrowth zones

Objasnienia: 1 - Dane dla pierwszego roku analiz, 2 - Dane dla ostatniego roku analiz.

Explanations: 1 - Data for the first year of analysis, 2 - Data for the last year of analysis. 
Aby wyznaczyć czynnik decydujący o rozwoju lub regresji powierzchni efektywnego zarastania uśredniono wartości temperatury oraz opadów dla okresów chłodnych oraz ciepłych. Okres chłodny utożsamiany jest z pierwszą połową roku hydrologicznego i obejmuje miesiące od listopada do kwietnia. Analogicznie okres ciepły odnosi się do drugiej połowy roku hydrologicznego. Następnie wykonano analizę korelacji liniowej Pearsona między powierzchnią efektywnego zarastania a ww. czynnikami meteorologicznymi, co pozwoli na odkrycie istniejących analogii.

W Polsce wykorzystanie indeksu NDVI dotyczyło w zasadzie rozpoznawania użytków zielonych (Kosiński, Kozłowska 2003; Kosiński, Hoffmann-Niedek 2008), w tym oceny warunków wodnych - uwilgotnienie (Kozłowska i in. 2004) oraz analizy zmian określonych siedlisk i zbiorowisk, a także monitorowania zmian środowiska przyrodniczego (Głowienka, Michałowska 2007) oraz zastosowania w pracach klimatologicznych (Walawender 2009). W przypadku zarastania jezior indeks ten w zasadzie nie był użyty. Podobną sytuację można zaobserwować w literaturze obcojęzycznej, gdzie dominują prace związane z wykorzystaniem indeksu NDVI do celów określania zmian środowiska przyrodniczego (DeFries, Townshend 1994; Carlson, Ripley 1997; Chen i in. 2004). Pojedyncze prace analizujące NDVI w aspekcie zarastania jezior przedstawiono szczegółowo w dyskusji. W literaturze naukowej zjawisko zmian liczby i powierzchni jezior, w tym efektu zarastania, oparte było w ostatnich latach najczęściej na analizie materiałów kartograficznych i przy wykorzystaniu narzędzi GIS (Nowacka, Ptak 2007; Choiński, Ptak 2008; Grandke 2009; Ptak 2013a, b; Piasecki 2013; Choiński i in. 2014; Krąż i Piasecki 2015; Marynowska 2018).

\section{Uzyskane wyniki}

Analizę obszarów aktywnego zarastania przeprowadzono $100 \mathrm{~m}$ od brzegu jeziora dla lat 2000-2014. Za pomocą NDVI można również przeprowadzić badanie roślinności poza strefą bufora (w rozumieniu obszaru położonego powyżej $100 \mathrm{~m}$ - brzeg jeziora). Istnieje jednak ryzyko, obarczone błędem ze względu na rozmywanie się wartości indeksu NDVI roślinności oraz otaczającej wody, co wymusza obniżenie wartości granicznej indeksu, od której obliczana będzie strefa efektywnego zarastania. Istotną rolę odgrywa tu $19 \mathrm{~m}$ rozdzielczość rastra wynikowego. Dla poniższej analizy wynosiła ona (-0.42) i została wykonana w celu wizualizacji dla roku 2014.

Szacunkową zmienność zasięgu zarastania brzegowego oraz określenie największego i najmniejszego obszaru transgresji roślinności wodnej na przestrzeni lat 2000-2014 ukazują ryciny 3 i 4. Latami, w których proces ten był widoczny najintensywniej (>15 ha) są 2008, 2010, 2012 oraz 2014. W roku 2014 powierzchnia jeziora była największa i wynosiła 18,09 ha w obrębie strefy $100 \mathrm{~m}$ od linii brzegowej. Najsłabiej zjawisko to było widoczne w latach 2001, 2003 oraz 2011. Warta odnotowania 

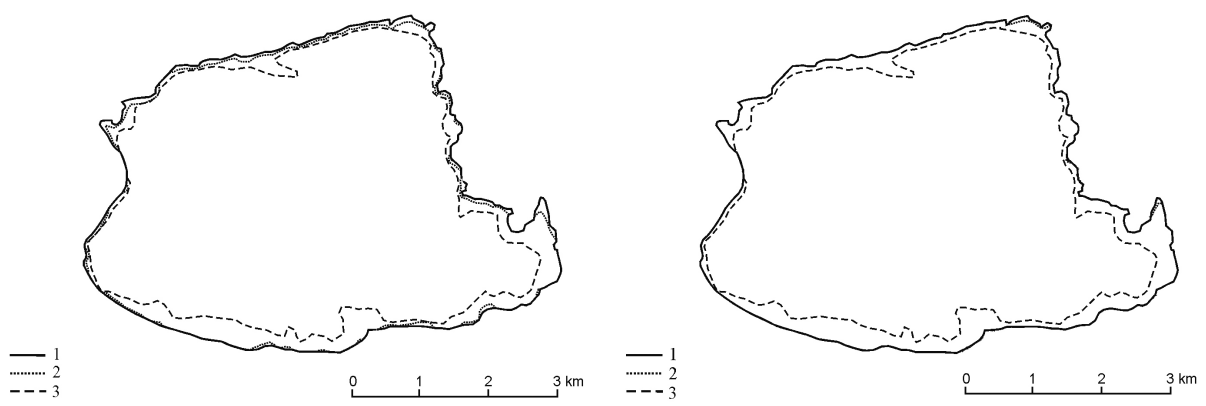

Ryc. 3. Szacunkowa zmienność zasięgu zarastania brzegowego dla jeziora Gardno w latach 2000-2014

Fig. 3. Estimated variability of coastal overgrowth range for Lake Gardno in the years 2000-2014

Objasnienia: 1 - Linia brzegowa jeziora Gardno, 2 Szacunkowy zasięg zarastania brzegowego w roku 2000, 3 - Szacunkowy zasięg zarastania brzegowego w roku 2014.

Explanations: 1 - Coastline of Lake Gardno, 2 - Estimated variability of coastal overgrowth range for Lake Gardno in the year 2000, 3 - Estimated variability of coastal overgrowth range for Lake Gardno in the year 2014.
Ryc. 4. Szacunkowy zasięg największej i najmniejszej transgresji roślinności wodnej brzegowej w latach 2000-2014

Fig. 4. Estimated range of the largest and the smallest transgression of coastal vegetation in the years 2000-2014

Objaśnienia: 1 - Linia brzegowa jeziora Gardno, 2 - Szacunkowy zasięg największej i najmniejszej transgresji roślinności wodnej brzegowej w latach 2000-2014 (2003), 3 - Szacunkowy zasięg największej i najmniejszej transgresji roślinności wodnej brzegowej w latach 2000-2014 (2014).

Explanations: 1 - Coastline of Lake Gardno, 2 - Estimated range of the largest and the smallest transgression of coastal vegetation in the years 2000-2014 (2003), 3 - Estimated range of the largest and the smallest transgression of coastal vegetation in the years 2000-2014 (2014).

jest wartość osiągnięta w roku 2003, wynosząca zaledwie 0,6 ha, będąca najniższą zanotowaną wartością w obrębie całego 15-lecia. Uzyskane wyniki zestawiono w formie tabelarycznej (tab. 1).

Porównując przestrzenny rozkład obszaru efektywnego zarastania, wyraźnie zaznaczają się 3 strefy intensyfikacji tego procesu. Pierwszą z nich jest strefa południowego brzegu akwenu z nieznaczną dominacją w obrębie jej wschodniej części. Powodem wzmożonej ekspansji roślinności na tym obszarze może być oddziaływanie znajdujących się na południu polderów. Kolejną strefą jest najbardziej na wschód wysunięta 
część linii brzegowej jeziora Gardno. Przyczyną zintensyfikowania procesów w owym miejscu jest najprawdopodobniej obecny tam dopływ potamiczny, ze szczególnym uwzględnieniem największego dopływu do jeziora, rzeką Łupawą. Dodatkowo należy stwierdzić, że Łupawa dostarcza do jeziora Gardno 3,73 tys. ton materiału rocznie, co daje wypłycenie rzędu $0,06 \mathrm{~mm}$ rocznie (Balicki 1980). Według Tobolskiego i in. (1997) jezioro Gardno wskutek zamulania materiałem niesionym przez rzekę Łupawę w ciągu ostatnich 60 lat zmniejszyło swoją powierzchnię o około 100 ha, co stanowi 4\% lustra wody. Ostatnią wyraźnie zaznaczającą się strefą jest położony na północy obszar brzegowy jeziora. Efektem tego stanu rzeczy wydaje się być proces lądowienia obszaru między wydmami a jeziorem zlokalizowanym na północy. Zmiany w poszczególnych jeziorach wynikają często z wypłycania na skutek przesuwania się pasa mierzejowego (Hildebrandt-Radke 1999) graniczącego z jeziorami od strony północnej. Według Miszalskiego (1973) tempo zmian linii brzegowej jeziora Łebsko w latach 1891-1965 wyniosło od 0,5 do 1,2 $\mathrm{m} \mathrm{rok}^{-1}$. Można zatem założyć, że tempo zmian linii brzegowej jeziora Gardno będzie zbliżone do tego dla jeziora Łebsko.

Wpływ na wypłycanie misy jeziora Gardno, jak już wcześniej wspomniano, ma przede wszystkim silne zarastanie. Do zarastania przyczyniają się głównie trzcinowe szuwary, które powodują cofanie się lustra wody w tempie $0,3-3,0 \mathrm{~m} \mathrm{rok}^{-1}$ (Piotrowska 1997). Według Choińskiego i Kanieckiego (2003) szuwary trzcinowe zajmują na obszarze jeziora Gardno pas o szerokości dochodzącej nawet do kilkuset metrów, zaś powierzchniowo 4,1\% zwierciadła wody. W okresie 1912-1959 powierzchnia jeziora Gardno zmniejszyła się o $32 \mathrm{ha}$. Szacowana powierzchnia zarastania obecnie wynosi $4 \%$. W ciągu ostatnich 50 lat objętość jeziora zmniejszyła się w związku z tym o $6 \mathrm{mln} \mathrm{m}^{3}$ (Schechtl 1984), co stanowi około 16\% jego objętości.

Rozkład zmienności zarastania efektywnego na jeziorze Gardno jest zróżnicowany. Wyraźnie zaznaczają się lata ze wzmożoną intensywnością procesu oraz lata 
wyraźnego spadku jego intensywności. Biorąc pod uwagę 15-lecie, proces wykazuje tendencję wzrostową. Równanie linii trendu $(\mathrm{y}=0.005 \mathrm{x}-10.81)$ dla powierzchni wyrażonej w hektarach powoduje, iż funkcja opisana tym wzorem ze względu na pierwszy parametr wskazuje na wzrost powierzchni zarastania efektywnego z czasem (ryc. 5). Jest to naturalny proces cechujący wszystkie jeziora w obecnym klimacie.

Analiza korelacji między zmiennością powierzchni efektywnego zarastania a wartościami opadów i temperatury, uśrednionymi dla okresów chłodnych oraz ciepłych, daje zróżnicowane rezultaty. Na potrzeby niniejszej pracy ustalono, iż wartością korelacji liniowej Pearsona, która daje przypuszczenia, iż związek między wyznaczonymi zmiennymi nie jest jedynie dziełem przypadku $(\mathrm{k} \in<-1 ;-0,3>\cup<0,3 ; 1>)$, osiągnięta została jedynie dla związku powierzchni efektywnego zarastania a temperaturą w chłodnym okresie roku hydrologicznego, bezpośrednio poprzedzającym okres wegetacyjny roślin. Korelacja ta wynosi 0,407.

Biorąc pod uwagę poszczególne miesiące, największa korelacja została osiągnięta dla badanego związku w grudniu oraz marcu, korelacja wyniosła odpowiednio 0,465 oraz 0,403 . Taki stan rzeczy może być powodowany przemarzaniem roślin w okresie zimowym oraz znacznym ich wychładzaniem na początku okresu wegetacyjnego, co może wpływać na spowalnianie rozwoju flory w następującym okresie ciepłym. Wyniki te zaprezentowano w tabeli 2 oraz na rycinie 6.

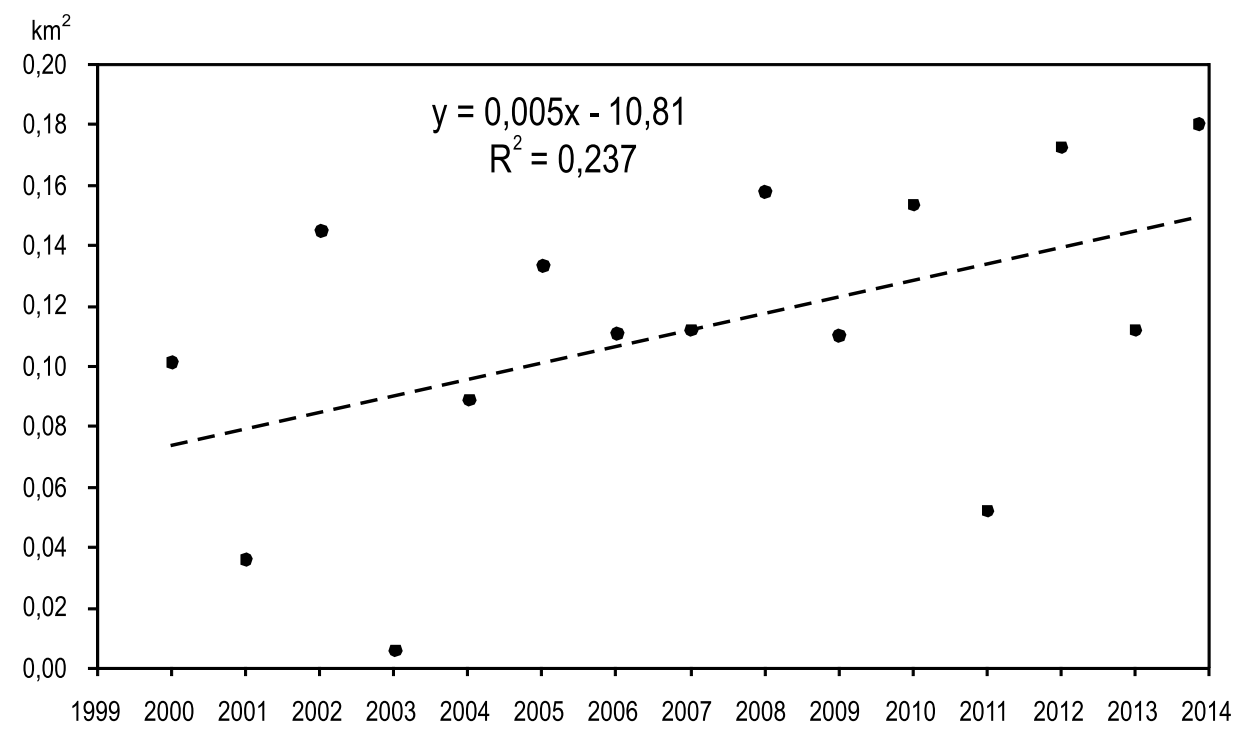

Ryc. 5. Zmiany powierzchni efektywnego zarastania wraz z trendem liniowym

Fig. 5. Changes in the area of effective overgrowth along with the linear trend 
Tab. 2. Wartość współczynnika korelacji liniowej Pearsona dla temperatury powietrza i opadów atmosferycznych w okresach ciepłych i chłodnych w odniesieniu do powierzchni efektywnego zarastania

Table 2. Value of the Pearson's linear correlation coefficient for air temperature and precipitation in warm and cold periods with respect to effective overgrowth

\begin{tabular}{|c|c|c|c|c|}
\hline & $\begin{array}{c}\mathrm{T} \text { (okres chłodny) } \\
\mathrm{T} \text { (cold season) }\end{array}$ & $\begin{array}{c}\mathrm{T} \text { (okres ciepły) } \\
\mathrm{T} \text { (warm season) }\end{array}$ & $\begin{array}{c}\mathrm{P} \text { (okres chłodny) } \\
\mathrm{P} \text { (cold season) }\end{array}$ & $\begin{array}{c}\mathrm{P} \text { (okres ciepły) } \\
\mathrm{P} \text { (warm season) }\end{array}$ \\
\hline $\begin{array}{c}\text { Wartość } \\
\text { korelacji } \\
\text { correlation } \\
\text { value }\end{array}$ & $0,407^{\star}$ & 0,039 & 0,097 & $-0,105$ \\
\hline
\end{tabular}

Objasnienia: T - temperatura powietrza, P - opady atmosferyczne, * - wartość istotna statystycznie na poziomie $\mathrm{p}=0,2$.

Explanations: $\mathrm{T}$-air temperature, $\mathrm{P}$ - precipitation, ${ }^{*}$ - statistically significant value at $\mathrm{p}=0,2$.

${ }^{\circ} \mathrm{C}$

$\mathrm{km}^{2}$
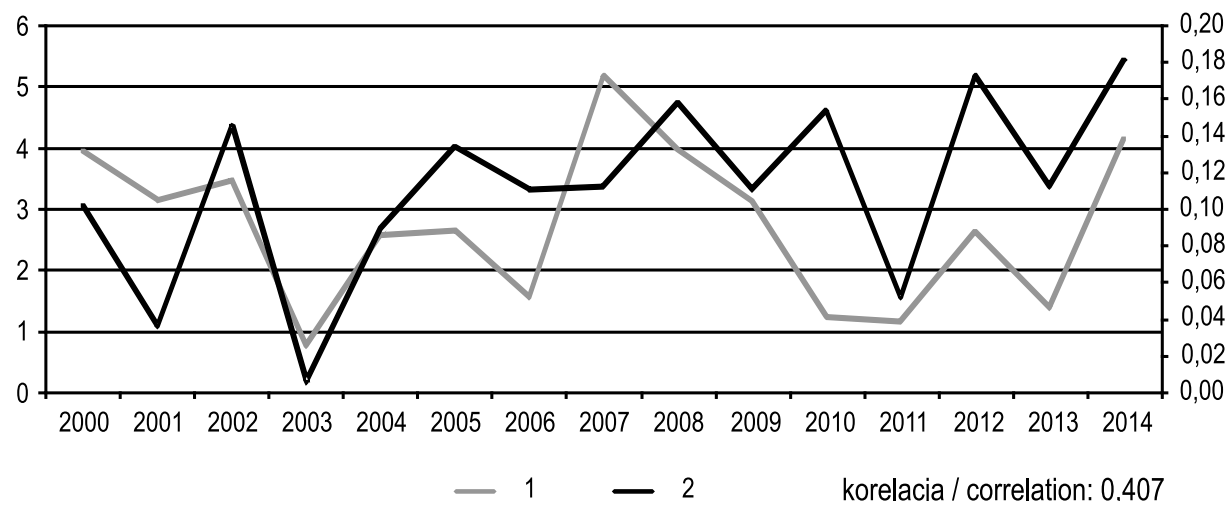

Ryc. 6. Zmiana powierzchni efektywnego zarastania oraz zmiany temperatury w chłodnym okresie poprzedzającym okres wegetacji

Fig. 6. Change in the surface of effective overgrowth and temperature changes in the cool period preceding the growing season

Objasnienia: 1 - temperatura w chłodnej porze roku, 2 - powierzchnia efektywnego zarastania.

Explanations: 1 - temperature in the cold season, 2 - area of effective overgrowth. 


\section{Dyskusja}

W literaturze polskiej, dotyczącej zarastania zbiorników wodnych, najczęściej stosuje się tradycyjne metody określenia ekspansji roślinności wodnej. Oprócz pomiarów wykonywanych w terenie bardzo często autorzy prac dokonują weryfikacji kartograficznej w celu jak najdokładniejszego prześledzenia zmian w wieloleciu. Choiński (2007) oszacował, iż żywotność jezior zlokalizowanych na Niżu Polskim wynosi od kilkuset do 2 tysięcy lat. Istnieją przypadki przejawiające się znacznie szybszym procesem zaniku niecki jeziornej, trwającej nawet kilkadziesiąt lat. Według Nowackiej i Ptaka (2007) w ciągu ostatnich 100 lat na Pojezierzu Wielkopolsko-Kujawskim liczba jezior zmniejszyła się pod wpływem zarastania o 23\%. Z kolei według obliczeń Marynowskiej (2018) powierzchnia jezior na Pojezierzu Iławskim zmniejszyła się o 8\% w latach 1893-2014. Metodyka związana z określeniem wielkości i tempa procesu zaniku jest dość często przytaczana w polskiej literaturze. W swoich badaniach Choiński i Ptak (2008) skupili się na zastosowaniu metody pozwalającej określić przebieg zaniku jezior zlokalizowanych na terenie Wielkopolski w porównaniu z innymi regionami Polski. W tym celu dokonali analizy powierzchni jezior oraz wypłycania misy jeziornej na skutek dostawy osadów dennych. Metoda, jaką obrali autorzy opracowania, była związana z weryfikacją materiałów kartograficznych. Jednocześnie autorzy opracowania wskazują na dokładność zastosowanej metody oraz duży nakład pracy i kosztów związanych z podejmowaną tematyką badawczą. Wynikiem przeprowadzonych analiz było oszacowanie, iż w ciągu 50 lat powierzchnia jezior poddanych weryfikacji uległa znacznemu zmniejszeniu w porównaniu z powierzchnią jezior zlokalizowanych na pojezierzach Pomorskim i Mazurskim, gdzie zanik nie postępował tak dynamicznie jak w przypadku jezior Pojezierza Wielkopolsko-Kujawskiego (Choiński, Ptak 2008).

Powyższe wnioski uzasadnia obliczony przez Kowalczyk (1993) współczynnik zarastania jezior roślinnością litoralną, wynoszący odpowiednio dla Pojezierza Wielkopolsko-Kujawskiego 7,3\%, dla Pojezierza Mazurskiego 4\%, a z kolei dla Pojezierza Pomorskiego 2,8\%. Autorzy opracowania wskazują, iż głównymi czynnikami wpływającymi na uzyskane wyniki są: szeroko pojęta działalność człowieka przejawiająca się ingerencją w system hydrograficzny tamtejszych zlewni, a także intensywna działalność rolnicza. Duża dostawa substancji biogenicznych oraz daleko posunięte prace melioracyjne znacząco przyczyniają się do rozwoju roślinności wodnej, a co za tym idzie stopniowego zaniku powierzchni jeziora (Choiński, Ptak 2008). Według Chlost (2010) czynnikiem sprawczym redukcji powierzchni wielu jezior, w tym jeziora Łebsko i jeziora Gardno stanowiącego obiekt badań, jest intensywny drenaż terenów, na których się znajdują, wynikający z przeprowadzonych prac melioracyjnych. Autorka oceniła, że w okresie 1836-1986 nastąpiło zmniejszenie powierzchni jeziora Łebsko o 546 ha (7,2\%), a Gardno o 237 ha (9,1\%). Pomimo 
zaprzestania odwodnienia proces kurczenia się lustra wody i ekspansji trzcinowisk w obu jeziorach nadal postępuje. Proces ten należy wiązać z następstwem oddziaływania efektów zmian klimatycznych widocznych od lat 80. ubiegłego wieku.

Współcześnie dzięki stale rozwijającej się technologii dającej coraz to nowe narzędzia można zbadać dane zjawisko zachodzące w środowisku przyrodniczym, niekoniecznie bazując na pracochłonnych pomiarach w terenie. Przykładami zastosowania nowoczesnych metod badawczych, przy wykorzystaniu analizy zdjęć satelitarnych, mogą pochwalić się nieliczni badacze w kraju, jak i za zagranicą. Metoda ta stanowi nowoczesne spojrzenie na procesy zachodzące w środowisku przyrodniczym i obecnie staje się popularną techniką przeżywającą swój rozkwit.

Zespół estońskich badaczy z Uniwersytetu Nauk o Życiu w Tartu przeprowadził badania mające na celu określenie wielkości i tempa zarastania jeziora Vortsjarv (Liira i in. 2010). Na podstawie zdjęć satelitarnych dokonali oni analizy roślinności porastającej badany zbiornik, zlokalizowany w południowej części kraju. Jezioro Vortsjarv charakteryzuje się dużą powierzchnią, mierzącą około 27000 ha, z kolei jego głębokość maksymalna wskazuje, iż jest to rodzaj płytkiego zbiornika, maksymalnie dochodzący do 6 m głębokości. Powierzchnia zlewni całkowitej jeziora wynosi 3100 km², a głównym ciekiem zasilającym jest Vaike Emajogi o długości 82 km. Otrzymane wyniki obserwacji, prowadzone w latach 1985-2007, wskazują na postępujący wzrost roślinności litoralnej do około $160 \%$ w porównaniu z początkowymi latami obserwacji. Roczny przyrost trzciny porastającej brzegi jeziora oszacowano na 2,2 m (Liira i in. 2010).

Podobną metodą określenia ekspansji roślinności wodnej posłużyła się grupa amerykańskich badaczy (Kiage, Walker 2009), dokonując analizy na podstawie wskaźnika wegetacji, dodatkowo wzbogacając to zdjęciami z satelity Modis. Obiektem ich obserwacji było jezioro Maracaibo, usytuowane w północno-zachodniej części Wenezueli. Badany zbiornik cechuje się bardzo dużą powierzchnią, mierzącą około 1434300 ha i odpowiednio dużą głębokością maksymalną dochodzącą do $250 \mathrm{~m}$. Analizie poddano stale powiększającą się populację rzęsy, która intensywnie zaczęła rozrastać się od 2004 r., z kolei obserwacje zapoczątkowano w 2003 r. i skończono w 2006 r. Rezultatem prowadzonych obserwacji jest odnotowanie zwiększenia się koncentracji rzęsy wodnej (wynosi ona maksymalnie $11 \% \mathrm{w}$ porównaniu z pierwszym rokiem badań). Cechą charakterystyczną jeziora Maracaibo jest fakt, iż jest ono połączone z Morzem Karaibskim oraz Oceanem Atlantyckim, a pomimo to masa wodna wypełniająca nieckę jeziorną jest słodka. Przyczyn stale powiększającej się populacji rzęsy należy upatrywać w zwiększonej dostawie substancji odżywczych oraz bardzo korzystnych warunkach klimatycznych stanowiących jeden z najważniejszych mechanizmów przyspieszających jej rozrost (Kiage, Walker 2009).

Kolejnym przykładem badań z zakresu zarastania jezior przez roślinność litoralną jest praca włoskich badaczy (Bresciani i in. 2009). W latach 1997-2005 przeprowadzili oni obserwację dwóch jezior zlokalizowanych w różnych częściach kraju. Pierwszym 
zbiornikiem poddanym analizie było jezioro Garda, usytuowane w północnych Włoszech. Jest to duże jezioro o powierzchni 37000 ha i bardzo głębokie, mierzące maksymalnie około 346 m. Główną rzeką zasilającą jezioro Garda jest Sarca, o długości 78 km. Drugim zbiornikiem poddanym obserwacji było jezioro Trazymeńskie, zlokalizowane w środkowych Włoszech, o powierzchni 12800 ha i głębokości maksymalnej dochodzącej do $8 \mathrm{~m}$. Cechą charakterystyczną badanych jezior jest ich lokalizacja na terenach zabagnionych. Analiza wskaźnika wegetacji wykazała, iż udział roślinności litoralnej ulegał zmniejszeniu, przy jednoczesnym przesuwaniu się linii brzegowej zbiorników, na skutek powiększających się terenów podmokłych w pobliżu jezior. Nad jeziorem Garda zaobserwowano regresje roślinności wodnej z 3600 m² w 1997 r.

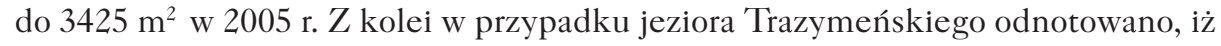
roślinność litoralna ulega zmniejszeniu od środka zbiornika o około 0,55 ha w ciągu każdego roku. Przyczyną otrzymanych rezultatów są specyficzne uwarunkowania hydrograficzne, decydujące o wielkości ekspansji trzciny porastającej badany zbiornik. Nadmiar wody pochodzący z pobliskich obszarów podmokłych zalewa skupiska trzciny, doprowadzając do jej gnicia, co w efekcie skutkuje zmniejszeniem jej populacji w obrębie badanego jeziora (Bresciani i in. 2009).

Według badań Papastergiadou i in. (2008), przeprowadzonych dla jeziora Cheimaditida położonego w północnej Grecji, przy wykorzystaniu narzędzi GIS, obszary, na których widoczne jest lustro wody narażone są na ekspansję trzcinowisk. W okresie około 50 lat powierzchnia trzcinowisk wzrosła w jeziorze o 19\%, gdy powierzchnia obszarów wodnych spadła o 99,5\%. Wpływ na rozwój trzcinowisk może mieć niekontrolowany dopływ związków biogennych, a przede wszystkim związków azotowych (Mitch, Day Jr. 2006).

Reasumując, można stwierdzić, że coraz ważniejsza staje się ocena, w jaki sposób zmiany środowiskowe wpływają na rozkład i dynamikę siedlisk roślinnych, aby umożliwić m.in. lepsze przewidywanie skutków globalnego ocieplenia, zmniejszenia różnorodności biologicznej lub degradacji siedlisk. Zdolność do przewidywania reakcji ekologicznych często utrudniały ograniczona znajomość interakcji troficznych oraz ograniczona informacja o roślinności w skali czasowej i przestrzennej. Niedawno zmieniła się jednak sytuacja, co wynika z możliwości wykorzystania NDVI w badaniach ekologicznych (Pettorelli i in. 2005).

\section{Wnioski}

Analizowana metoda może posłużyć do badań wielkości i tempa zarastania efektywnego jezior na przestrzeni analizowanego obszaru i w pewnych okolicznościach zastąpić drogie i czasochłonne badania w terenie. W obecnej analizie wykorzystano 15 zdjęć satelitarnych z okresu 15 lat, jednak narzędzie to pozwala z dużym 
powodzeniem zagęścić krok czasowy, co pozwoli śledzić bieżący rozwój roślinności. W przypadku analizowanego jeziora Gardno powierzchnia efektywnego zarastania wzrosła o 7,91 ha w latach 2000-2014, jednak proces ten nie ma charakteru płynnego. Najsilniej zjawisko to odznacza się w południowej, północnej oraz wschodniej części jeziora w obrębie strefy brzegowej. Wielkość powierzchni zarastania efektywnego zależy przede wszystkim od temperatury w okresie chłodnym, poprzedzającym badany okres wegetacyjny. Mimo iż metoda ta daje wymierne rezultaty w obrębie $100 \mathrm{~m}$ od linii brzegowej, tak jak w przypadku każdej metody komputerowej, w celu uzyskania większej pewności należałoby przeprowadzić dodatkowo badania terenowe w okresie analiz. Z uwagi na skupienie się głównie na roślinności brzegowej i pływającej, posłużono się jedynie danymi pochodzącymi z satelity Landsat 7.

\section{Literatura}

Balicki H., 1980, Szkic hydrograficzny zlewni jeziora Gardno, Wiadomości IMGW, 4, 8-10.

Bresciani M., Stroppiana D., Fila G., Montagna M., Giardino C., 2009, Monitoring reed vegetation in environmentally sensitive areas in Italy, Rivista Italiana di Terelirevamento, 41 (2), 125-137.

Carlson T.N., Ripley D.A., 1997, On the relation between NDVI, fractional vegetation cover, and leaf area index, Remote sensing of Environment, 62 (3), 241-252.

Chen J., Jönsson P., Tamura M., Gu Z., Matsushita B., Eklundh L., 2004, A simple method for reconstructing a high-quality NDVI time-series data set based on the Savitzky-Golay filter, Remote sensing of Environment, 91 (3), 332-344.

Choiński A. Ptak M., Strzelczak A., 2014, Present-day evolution of coastal lakes based on the example of Jamno and Bukowo (the Southern Baltic coast), Oceanological and Hydrobiological Studies, 43 (2), 178-184.

Choiński A., 2007, Limnologia fizyczna Polski, Wydawnictwo Naukowe UAM, Poznań.

Choiński A., 2014, Przyktady zaniku jezior w Polsce i ich przyczyny [w:] R. Cieśliński. K. Jereczek-Korzeniewska (red.), Problemy badań wody w XX i XXI wieku, Wyd. UG, Gdańsk, 66-81. Choiński A., Kaniecki A., 2003, Plan ochrony Stowińskiego Parku Narodowego, Poznań (maszynopis).

Choiński A., Ptak M., 2008, Zanikanie jezior w Wielkopolsce na tle Polski, Roczniki Gleboznawcze, 59 (2), 25-31.

Choiński A., Ptak M., 2013, Zmiany powierschni i batymetrii wybranych jezior Pojezierza Pomorskiego, Prace Geograficzne, 133, 61-76.

Cieśliński R., 2011, Geograficะne uwarunkowania zmienności hydrochemicznej jezior wybræęa potudniowego Battyku, Wyd. UG, Gdańsk.

Chlost I., 2010, Kartograficæny sapis zmian sieci wodnej Niziny Gardneńsko-Lebskiej w okresie XIX $i$ XX wieku [w:] A. Kaniecki, A. Baczyńska (red.), Zmiany stosunków wodnych w czasach historycznych, Studia i Prace z Geografii i Geologii, 9, Wyd. Bogucki, Poznań, 17-31.

DeFries R.S., Townshend J.R.G., 1994, NDVI-derived land cover classifications at a global scale, International Journal of Remote Sensing, 15 (17), 3567-3586. 
Głowienka E., Michałowska K., 2007, Mo:́liwość monitorowania smian środowiska z u̇̇yciem naræędzi GIS na przyktadzie Stowinskiego Parku Narodowego, Archiwum Fotogrametrii, Kartografii i Teledetekcji, 17, 241-249.

Grandke M., 2009, Zmiany powierzchni jeжior Breńskie i Biate-Miatkie (Pojezierze Stawskie) w latach 1778-2008, Studia Limnologica et Telmatologica, 3 (1), 3-24.

Hargrove W.W., Stoms D.M., 2000, Potential NDVI as a baseline for monitoring ecosystem functioning, International Journal of Remote Sensing, 21 (2), 401-407.

Hildebrandt-Radke I., 1999, Bilans transportu eolicznego na plaży mierzei Gardnieńsko-Łebskiej, [w:] K. Borówka, Z. Młynarczyk, A. Wojciechowski (red.), Ewolucja geosystemów nadmorskich potudniowego Battyku, Wyd. Bogucki, Poznań-Szczecin, 79-86.

http://fotoraporty.pl/oferta/teledetekcja/ndvi/ (dostęp: 17.09.2018).

https://earthexplorer.usgs.gov/ (baza danych) (dostęp: 17.09.2018).

https://en.tutiempo.net/climate/poland.html (dostęp: 12.12.2017).

Jańczak J., 1997, Atlas jezior Polski. Jeziora zlewni rzek Przymorza i dorzecza dolnej Wisty, Wyd. Bogucki, Poznań.

Kiage L, Walker N., 2009, Using NDVI from MODIS to monitor duckweed bloom in lake Maracaibo: Venezuela, Water Resources Management, 6, 1125-1135.

Kondracki J., 2000, Geografia regionalna Polski, PWN, Warszawa.

Kosiński K., Hoffmann-Niedek A., 2008, Klasyfikacja obiektowa üytków sielonych z wykorzystaniem wieloletnich :mian NDVI i filtracji kierunkowych obrazu satelitarnego, Archiwum Fotogrametrii, Kartografii i Teledetekcji, 18, 273-282.

Kosiński K., Kozłowska T., 2003, Zastosowanie wskasnika NDVI i filtracji kierunkowej do rozpoznawania üytkow zielonych oraz analizy zmian siedlisk $i$ zbiorowisk takowych, Archiwum Fotogrametrii, Kartografii i Teledetekcji, 13, 387-395.

Kowalczyk V., 1993, Zrón̈nicowanie zarastania jezior w zlewniach wobrębie wydzielonych pojezierzy, MS, Instytut Geografii UAM, Poznań.

Kozłowska T., Kosiński K., Kwiecień R., Ziaja W., 2004, Zastosowanie wskaznika NDVI do wyróżniania łą o ró:̇nym poziomie użytkowania i uwilgotnienia, Woda-Środowisko-Obszary Wiejskie, 4, 201-218.

Krąż P., Piasecki A., 2015, Zmiany misy jeziora Bobięcinskiego Wielkiego zwykorzystaniem narzędzi GIS, Współczesne problemy i kierunki badawcze w geografii, 3, 197-206.

Kunz M., Nienartowicz A., 2007, Zmiennośćprzestrzenna NDVI i wskaźników tekstury Zaborskiego Parku Krajobrazowego w zależności od gospodarczego oddziatywania cztowieka, Teledetekcja Środowiska, 37, 51-60.

Liira J., Feldman T., Maemets H., Peterson U., 2010, Two decades of macrophyte expansion on the shores of a large shallow northern temperate lake - A retrospective series of satellite images, Aquatic Botany, 93, 207-215.

Marynowska W.C., 2018, Analysis and visualisation of lake disappearance process in Itawa Lakeland Landscape Park, Quaestiones Geographicae, 37(1), 115-124. 
Miszalski J., 1973, Wspótcæesne procesy eoliczne na Pobræeżu Stowinskim. Studium Fotointerpretacyjne, Dokumentacja Geograficzna Instytutu Geografii PAN, 1-182.

Mitsch W.J., Day Jr. J.W., 2006, Restoration of wetlands in the Mississippi-Ohio-Missouri (MOM) River Basin: Experience and needed research, Ecological Engineering, 26 (1), 55-69.

Nowacka A., Ptak M., 2007, Zmiany powierzchni jezior na Pojezierzu Wielkopolsko-Kujawskim $w X X$ w., Badania Fizjograficzne nad Polską Zachodnią, Seria A - Geografia Fizyczna, 58, $149-157$.

Papastergiadou E.S., Retalis A., Apostolakis A., Georgiadis Th., 2008, Environmental monitoring of spatio-temporal changes using remote sensing and GIS in a Mediterranean wetland of Northern Greece, Water Resources Management, 22 (5), 579-594.

Pettorelli N., Vik J. O., Mysterud A., Gaillard J. M., Tucker C. J., Stenseth N. C., 2005, Using the satellite-derived NDVI to assess ecological responses to environmental change, Trends in Ecology \& Evolution, 20 (9), 503-510.

Piasecki A., 2013, Zmiany powierzchni jezior Pojezierza Dobrzyńskiego w świetle materiałów kartograficznych, Prace Geograficzne, 132, 39-57.

Piotrowska H. (red.), 1997, Przyroda Stowińskiego Parku Narodowego, Wyd. Bogucki, Poznań-Gdańsk.

Ptak M., 2013a, Zmiany powierzchni i batymetrii wybranych jezior pojezierะa pomorskiego, Prace Geograficzne, 133, 61-76.

Ptak M., 2013b, Lake evolution in the Żnin region in the years 1912-1960 (central Poland), Quaestiones Geographicae, 32 (1), 21-26.

Rouse J.W., 1978, Monitoring the vernal advancement and retrogradation (green wave effect) of natural vegetation, Remote Sensing Center, Texas University.

Schechtl A., 1984, Plan uræadzenia gospodarstwa leśnego na okres 1.01.1983 do 31.12.1992, Słowiński Park Narodowy, I: część ogólna planu, Mscr., BULIGL oddział w Szczecinku.

Tobolski K., Mocek A., Dzięciołowski W., 1997, Gleby Stowińskiego Parku Narodowego w świetle historii roślinności i podto:̇a, Domini, Bydgoszcz- Poznań.

Walawender J., 2009, Wykorzystanie danych satelitarnych Landsat i technik GIS w badaniach warunków termicznych miasta (na przyktadzie aglomeracji krakowskiej), Prace Geograficzne, 122, 81-98.

\section{Kamil Mironik \\ Uniwersytet Gdanski \\ Katedra Hydrologii \\ ul. Bä̀ńnskiego 4 \\ 80-952 Gdańsk \\ mirkamil@vp.pl}

\author{
Artur Mtodzik \\ Uniwersytet Gdański \\ Katedra Hydrologii \\ ul. Bażynskiego 4 \\ 80-952 Gdańsk \\ arturro19@onet.pl
}

\author{
Roman Cieślinski \\ Uniwersytet Gdański \\ Katedra Hydrologii \\ ul. Bażyńskiego 4 \\ 80-952 Gdańsk \\ georc@univ.gda.pl
}


